\title{
The Impact of Using a Single Image in a Representation on a Misconception of Fraction Concept
}

\author{
Aisyah Turidho ${ }^{1}$ Indah Widya Astuti ${ }^{2}$ Kori Auga Islamirta ${ }^{3}$ Selly Dian Utami Sitio \\ Yulianita Maharani ${ }^{5}$ Darmawijoyo $^{6, *}$ Somakim $^{7}$
}

1,2,3,4,5,6,7 Mathematics Education Department, Universitas Sriwijaya, Palembang, South Sumatera, Indonesia *Corresponding author. Email: darmawijoyo@unsri.ac.id

\begin{abstract}
This research aims to describe the impact of using a single image in representation on understanding the concept of fractions. The subjects in this study were six students in grades 4-7. The data collection technique used in this research is interviews conducted on research subjects one by one. Students' limitations in understanding the concept of fractions are caused by using a single image in the representation so that students had difficulty dealing with two aspects of the image in the representation, namely the difference in size and shape. The results showed that in comparing two fractions originating from a circle of different sizes, students predominantly assume that the fraction from the largest slice of the circle is the fraction that has the greatest value. There are still students who cannot state a fraction of a part that has a different way of dividing from what they usually encounter. There are still students who are affected that two parts with different shapes have different areas even though the two parts come from a flat building with the same size.
\end{abstract}

Keywords: Single-Image, Representation, Misconception, Fraction.

\section{INTRODUCTION}

A fraction is one of the most important mathematical materials for students to understand. This importance is because understanding its concept is a basic skill in mathematics that can make mathematics learning more advanced [1, 2]. Besides, it has an important role in learning mathematics to a higher level because these materials are the keys to number development theory which they allow students to deepen their knowledge of numbers beyond the levels that arise from the experience of integer and fraction are prerequisite materials for other numbers such as real and complex numbers [3-6].

Unfortunately, there are still so many students who have difficulty solving these problems related to fractions. This fact is in line with Alkhateeb [6], who stated that more than $50 \%$ experienced difficulties and made mistakes related to the application of fractions in a problem. This difficulty was caused by the students' limited understanding of the concept of fractions. Students' limitations in understanding the concept of fractions include comparing the values of two fractions and understanding the part of whole $[7,8]$.

In learning the concept of fractions, students are always presented with representations in the form of images. Van de Walle, Karp \& Bay-William [7],
Strother, Brendefur, Thiede \& Appleton [9], and Eichhorn [10] stated that representations would greatly help students in understanding fraction. However, so far, students had only introduced one single image representing a fraction, even though the representation in the form of an image greatly affects a person's belief system [11, 12]. It is feared that the belief system will cause students to interpret inaccurate interpretations of its concept, especially for images that have different sizes and shapes.

Previously, many researchers discussed the limitations of students in understanding fractions. Among others, Fitri \& Prahmana [13] explored information and described students' mistakes in solving problems related to fractions, Ghani \& Maat [14] described students' errors in adding fractions with different denominators, and Deringöl [15] investigated the teachers' knowledge and perspective regarding student misunderstandings on a fraction. However, no one has discussed the impact of using a single image in understanding the concept of fraction.

This is what makes researchers interested in describing the impact of using a single image on understanding the concept of fraction. In this research, researchers examined the effect of differences in size and 
shapes of an image representation presented on students' understanding of the concept of fractions.

\section{METHOD}

This research uses qualitative research because it aims to describe the impact of using a single image in representation on understanding the concept of fractions. The subjects in this study were six students in grades 47. In this research, the data collection technique was an interview in which the researcher interviewed the subjects one by one. This research was conducted on October 10-18, 2020, at several research subjects' and the researchers' house. On the interview, researchers ask about two aspect namely: different in size and different in shape. On the aspect different in size, the researchers gave two circles of different sizes to each subject, where each circle was divided into several parts. Each part was labeled with a fraction, as shown in Figure 1 below.
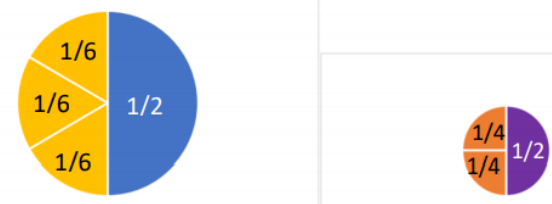

Figure 1 Two different size circles

Then the researchers took the yellow and orange circle pieces as in Figure 2 and asked the students to compare the sizes or numbers of $1 / 6$ and $1 / 4$ by paying attention to the two pieces.

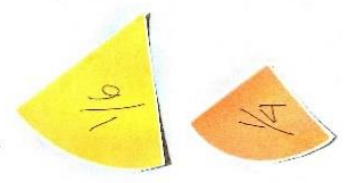

Figure 2 The cut of circle

Then, on the aspect different in shape, the researchers presented two same size rectangles. One rectangle was divided diagonally in half, while the other was divided vertically in half, where the part was labeled $1 / 2$ as in Figure 3 below.

Image A

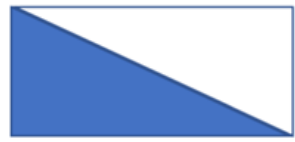

Image B

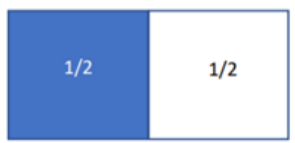

Figure 3 Two equal rectangles
The researchers asked each subject about the fraction from one of the parts in Image A (in Figure 3). After that, the researchers asked the subjects to compare the area of the blue part in image A with the blue part in image B (in figure 3). The results of the interview about different in size and different in shape were presented in the result and discussion section.

\section{RESULT AND DISCUSSION}

In this research, there are two aspects of image representation that students rarely encounter in fraction learning, the presentation of images with a difference in size and shape.

\subsection{Difference in Size}

From the result of interview, researchers found that in comparing the sizes between the yellow and orange cuts, all subjects answered that the yellow circle pieces were the greater ones because they were obvious. However, in comparing which one is greater between $1 / 4$ and $1 / 6$, the six research subjects had different answers, as shown in Figure 4 below.

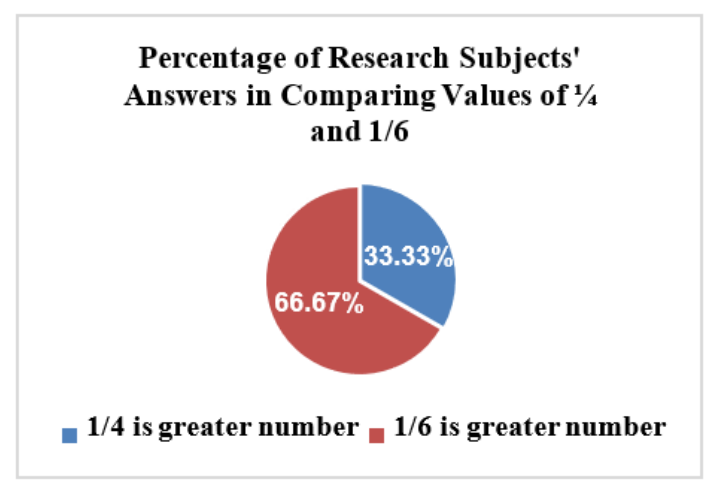

Figure 4 Percentage of research subjects' answers in comparing values of $1 / 4$ and $1 / 6$

From Figure 4, we know that subjects who answered $1 / 6$ greater than $1 / 4$ were $66.67 \%$, while those who answer $1 / 4$ were $33.33 \%$.

This fact shows that research subjects tend to be fooled by the image representations presented. One subject who was fooled and answered 1/6 greater than 1/4 was subject $X$. This can be seen in the following interview:

Researcher: "So which one is greater? 1/6 or 1/4 (Showing figure 2)" Subject X: "1/6"

Researcher: "Why?"

Subject X: "Because it is bigger (the circle) besides that, the number is also greater."

Apart from subject $\mathrm{X}$, other subjects who answered $1 / 6$ is greater than $1 / 4$ also gave the same reason. The 
subjects were fooled by what they saw because the image representation immediately made them believe that what they saw was true without examining it first $[11,12]$. Moreover, the subjects did not understand that circles of different sizes could not be compared in this case. This fact is in line with Lestiana, Rejeki \& Setyawan [16], which stated that sometimes students do not realize that the model or representation used must be the same size in comparing two fractions.

Meanwhile, the subject who answered correctly, which $1 / 4$ is greater than $1 / 6$, expressed the reason by the analogy of an object and did not consider the image representation (Figure 2) presented. One of them was subject Z, who used slices of cake as an analogy, namely a cake divided by four will produce a larger slice than a cake divided by 6 . When the subject was asked to refer to the image representation (Figure 2) presented, the subject did not want to do this because he felt something odd, even though he could not convey the odd thing. This fact shows that students had understood the meaning of part of the whole. Amato [17] stated that the part of whole model is the one most familiar to students as representing a fraction. That is what causes students to use the analogy of representing an object divided into several parts.

\subsection{Difference in Shape}

Figure 5 below illustrates the results of the subjects' answers about the fraction from one of the parts in Image A.

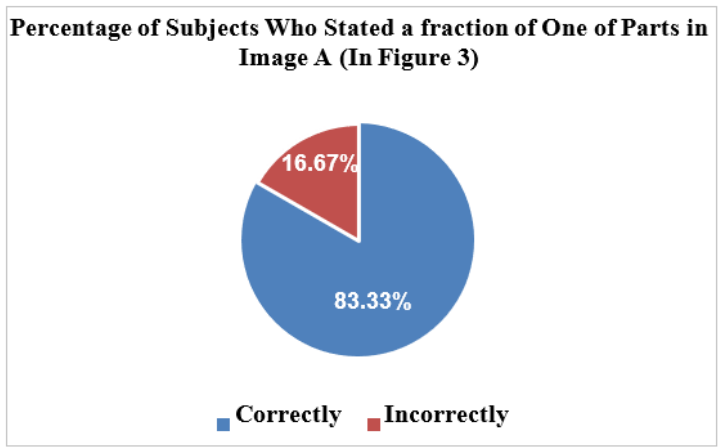

Figure 5 Percentage of subjects who stated the form of a fraction in image A (in figure 3 )

Based on Figure 5, it can be seen that $83.33 \%$ of students could correctly state the fraction from one of the parts in image A (in Figure 3) was 1/2. It was much more dominant than students who incorrectly mention the fraction of one of the parts in Image A, namely only $16.67 \%$. This is because $1 / 2$ is a very familiar fraction for students, and it is straightforward to conceptualize. Even children aged 3-4 years have a good representation of fraction $1 / 2$ [18], [19] and [20].

The subject who was wrong in stating the fraction of one of the parts in image A (in figure 3 ) is subject W. It can be seen in the following interview:
Researcher: "What is the shape of the fraction in the blue part? (in image A of figure 3)"

Subject W: "1/3 (looks confused and randomly answered)"

\section{Researcher: "Why?" Subject W: "I do not know."}

One shows that the subject did not really understand the part of whole [7] and [8] so that when an object is divided in different ways, the subject felt confused.

Then, figure 6 below shows the results of students' answers in comparing the blue area in Image A and B (in figure 3).

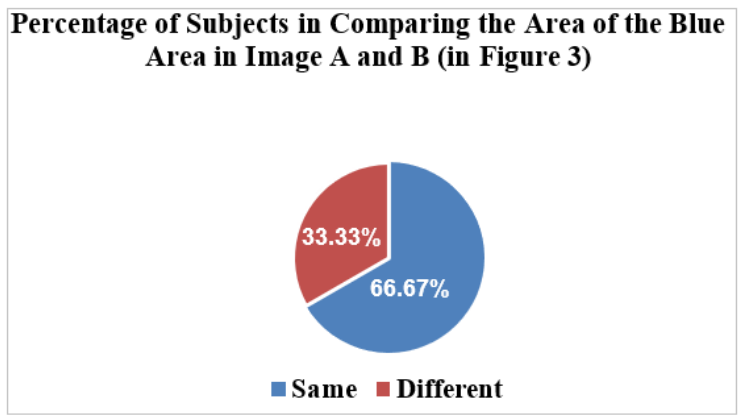

Figure 6 Percentage of subjects in comparing the area of the blue area in image A and B (in figure 3)

Based on Figure 6, the most dominant part of the subject answered the correct answer, namely, the area of the blue part of images A and B (in Figure 3) was the same, while $33.33 \%$ answered the wrong answer because it stated that the area was different. One of the subjects who answered the two sections that had the same area was subject $X$. It can be seen in the following interview excerpt:

Researcher: "What about the areas? (between the blue part in image A and B in figure 3) " Subject X: "Those are the same."

Researcher: "Why?"

Subject X: "Because both are half."

Subject $X$ assumed that due to the fraction of that shape, the two parts are the same, namely $1 / 2$, so that the areas are the same. Even subject X captured the two rectangles and ensured that the two shapes are the same size to make sure whether or not the area of the two blue halves in Figure 3 are the same. A similar reason was put forward by another subject who answered that the two blue parts in Figure 3 have the same area. This is because students understand part of whole and can determine the area of a shape using fractions [21].

Meanwhile, subject $\mathrm{Y}$ answered that the two blue sections had different areas. This can be seen in the following interview excerpt: 
Researcher: "Are the areas the same? (between the blue part in image A and B) "Subject Y: "They are different."

Researcher: "Why?"

Subject Y: "Because this is a square, but this is a triangle."

This information shows that the subject was affected by the difference in shapes of blue part in image A and B. This fact is due to the difference in shape in the image representations presented that affect the student's belief system so that students overly believe the different forms they see without considering other things [11] and [12]. The same thing was experienced by the subject who answered the area of the two blue parts in figure 3 are different, namely subject $\mathrm{W}$, who thought that because the length of the base on the blue triangle was much longer than the blue rectangle, it meant that the two blue parts had an different area where the triangle has a larger area.

\section{CONCLUSION}

There are several impacts of using a single image as a representation in learning fractions, including: In comparing two fractions originating from a circle of different sizes, students predominantly assume that the fraction from the largest slice of the circle is the fraction that has the greatest value because they don't realize that the two fractions originating from a circle that have different sizes cannot compared. There are still students who cannot state a fraction of a part that has a different way of dividing from what they usually encounter and it is due to a lack of understanding of part of the whole. There are still students who are affected that two parts with different shapes have different areas even though the two parts come from a flat building with the same size.

To follow up on this, it is suggested that in learning students are not only faced with a single image but also a representation that has a variety of sizes and shapes.

\section{REFERENCES}

[1] L.K. Fazio, C.A. Kennedy, R.S. Siegler, Improving children's knowledge of fraction magnitudes, PLOS ONE 11(10) (2016) 1-14. DOI: https://doi.org/10.1371/journal.pone.0165243

[2] B. Bentley, M.J. Bossé, College students' understanding of fraction operations, International Electronic Journal of Mathematics Education 13(3) (2018) 233-247. DOI: https://doi.org/10.12973/iejme/3881

[3] L. Khuriyati, Desain pembelajaran operasi pecahan menggunakan kertas berpetak di kelas IV, Numeracy
Journal 2(2) (2015) 104-114. DOI: https://doi.org/10.46244/numeracy.v2i2.166

[4] V. Trivena, A.R. Ningsih, A. Jupri, Misconception on addition and substraction of fraction at primary school students in fifth-grade, J. Phys.: Conf. Ser. 895 (012139) (2017). DOI: 10.1088/1742$6596 / 895 / 1 / 012139$

[5] Y. Widiastuti, R.I.I. Putri, Kemampuan berpikir kreatif siwa pada pembelajaran operasi pecahan menggunakan pendekatan open-ended, Jurnal Pendidikan Matematika 12(2) (2018) 13-22. DOI: https://doi.org/10.22342/jpm.12.2.5961.13-22

[6] M.A. Alkhateeb, Common errors in fractions and the thinking strategies that accompany them, International Journal of Instruction 12(2) (2019) 399-416.

DOI: https://doi.org/10.29333/iji.2019.12226a

[7] J.A. van de Walle, K.S. Karp, J. M. Bay-William, 2016 Elementary and middle school mathematics: Teaching developmentally (Eds. 9 th), USA, Pearson Education, 2016, pp. 363-394.

[8] Y.W. Purnomo, C. Widowati, S. Ulfah, Incomprehension of the Indonesian elementary school students on fraction division problem, Infinity Journal on Mathematics Education 8(1) (2019) 57-74. DOI: https://doi.org/10.22460/infinity.v8i1.p57-74

[9] S. Strother, J.L. Brendefur, K. Thiede, S. Appleton, Five key ideas to teach fractions and decimals with understanding, Advances in Social Sciences Research Journal 3(2) (2016) 132-137. DOI: https://doi.org/10.14738/assrj.32.1832

[10] M.S. Eichhorn, When the fractional cookie begins to crumble: Conceptual understanding of fractions in the fifth grade, IJRES 4(1) (2018) 39-54. DOI: 10.21890/ijres.382933

[11] M. Clarebout, F. Depaepe, J. Elen, J. Briell, The use of drawings to assess students' epistemological beliefs, Biannual Conference of the European Association for Reseach, 2007

[12] N.J.C. Trance, R.B. Marapo, J.B. Pornel, Students' visual representation of mathematics, J Korea Assoc. 32 (8) (2012) 1318-1332. DOI: https://doi.org/10.14697/jkase.2012.32.8.1318

[13] N.L. Fitri, R.C. Prahmana, Misconception in fraction for seventh-grade students J. Phys.: Conf. Ser. 1188 (012031) (2019). DOI: 10.1088/1742$6596 / 1188 / 1 / 012031$

[14] S.N Abdul Ghani, S.M. Maat, Misconception of Fraction among Middle Grade Year Four Pupils at 
Primary School, Research and Education on Psychology 2(1) (2018) 111-125.

[15] Y. Deringöl, Misconceptions of primary school students about the subject of fractions: Views of primary teachers and primary pre-service teachers, IJERE 8(1) (2019) 29-38. DOI: 10.11591/ijere.v8i1.16290

[16] H.T. Lestiana, S. Rejeki, F. Setyawan, Identifying students' errors on fractions, Journal of Research and Advances in Mathematics Education 1(2) (2016) 131-139

[17] S.M. Amato, Developing students' understanding of the concept of fractions as numbers, In H.L. Chick, J.L. Vincent (Eds.), Proceedings of the 29 th Conference of the International Group for the Psychology of Mathematics Education, Melborne, PME, Vol. 2, 2005, pp. 49-56.

[18] F. Gabriel, F. Coche, D. Szucs, V. Carette, B. Rey, A. Content, A componential view of children's difficulties in learning fractions, Frontiers in Psychology 4(715) (2013) 1-12. DOI: https://doi.org/10.3389/fpsyg.2013.00715

[19] M.M.M. Mazzocco, G.F. Myers, K. E. Lewis, L.B. Hanich, M.M. Murphy, Limited knowledge of fraction representations differentiates middle school students with mathematics learning disability (dyscalculia) versus low mathematics achievement, J. Exp. Child Psychol. 115(2) (2013) 371-387. DOI: 10.1016/j.jecp.2013.01.005

[20] F.K.E. Singer, U. Goswami, Does half a pizza equal half a box of chocolates? Proportional matching in an analogy task, Cognitive Development 16(3) (2001) 811-829. DOI: https://doi.org/10.1016/S0885-2014(01)00066-1

[21] M. Saleh, R.C.I Prahmana, M. Isa, Murni, Improving the reasoning ability of elementary school student through the Indonesian Realistic Mathematics Education, Journal on Mathematics Education 9(1) (2018) 41-45. DOI: https://doi.org/10.22342/jme.9.1.5049.41-54 